\title{
4. 産業プロテアーゼの細胞型進化工学による低温適応化
}

\author{
田口精一（東京理科大学・基礎工学部、(現) 理化学研究所・高分子化学)
}

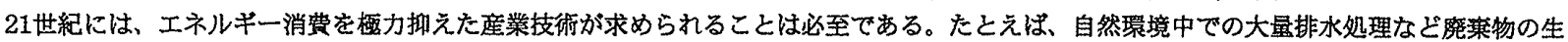
分解反店、低温下での食品加工プロセス、冷水使用の洗濯、寒冷地での瑟境浄化などでは、低温域で好ましい活性を発揮する醉素を創成するこ とは、基整・実用両面においてインパクトが大きい。我々は、産業の現場で使用されている微生物プロテアーゼ「サチライシン」をモデルとし

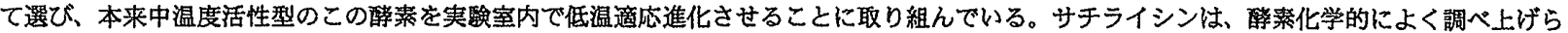

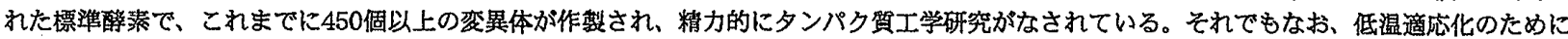

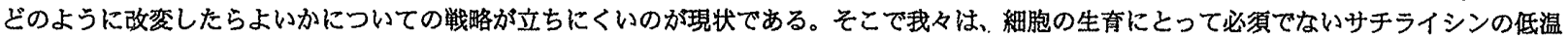
適応化の細胞型進化工学システムに活性復淿の原理を取り入れた戦略をとった。得られた低温適店型の変異位置は、醉素全体のうち前半部に集 中していることがわかった。このうち、 $\mathrm{m}-63$ と名つけた変異体は、10での合成基貲に対する分解活珄が野生㤠より100\%上开しており、72

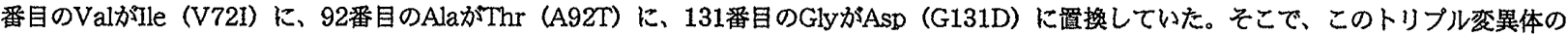

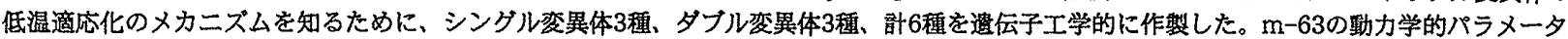
一から、m-63は主に基筫との親和性（Km值）に依存して低温適店が実現していることがわかった。また、A92TとG131Dの2つの変異がポジテ

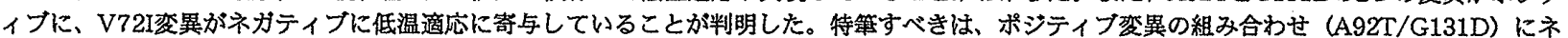
カティブ変巽 (V72I) が加わることでさらに活性上显を得られるということである。さらに、活性と同様に構造形成・安定性の両面でも進化の

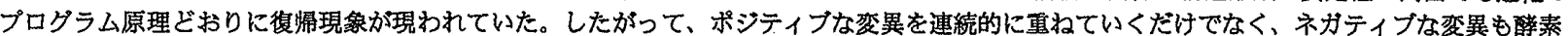
の機能進化には有效であることがこの例から学べた。このように、進化工学の手法によって低温適灾に関与するボジションが探り当てられてき たところで、低温適分位置の131番目に着目して、残りすべてのアミノ酸置換体を作製して、䣼素抗体とマイクロプレートを利用した䉮便型高

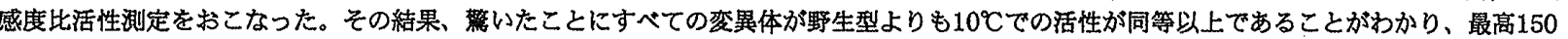
\%活性上昇をもたらす変異体が存在していた。自然界から見つけ出されたサチライシンのメンバー（いわぱ天然変異体）注200を超えるが、131 番目のアミノ酸の種類とそのサチライシン生産菌が探取された環境温度との間に恃別な関係性は䄊められなかった。おそらく、この131番は、

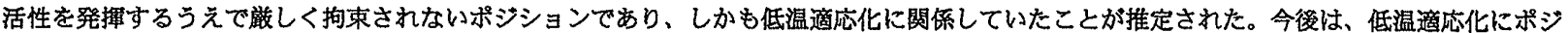
ティブな変簧点のシャフリングによる進化工学的分子育種が有効であると思われる。

\section{5. 好熱菌を材料とした分子育種}

山岸明彦（東京薬科大学、生命科学部）

我々は、これまで好熱菌Thermus thermophilus宿主として進化分子工学あるいは定向進化 (directed evolution) の実験を行ってきた。進

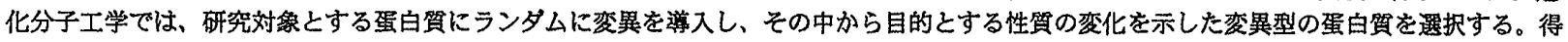

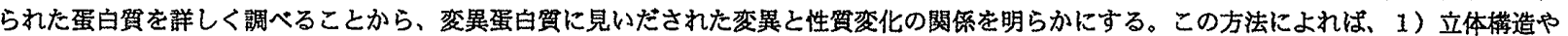
特性を改変するための理論なしで变異型蛋白質を得ることができ、2）変異型蛋白留を多数調べることにより变異導入の指針を得ることができ

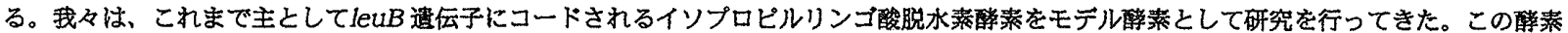
は、分子量約 3 万 5000 の単量体から成る 2 量体蛋白質である。それぞれの単量体俚二つのドメインより成っている。この䣼菜は菌体中で口 イシンの合成系に関与している。したがって、この醉素の欠損株はロイシンなしの培地では生育できない。つまり、この醉素の活性のあるなし が菌の生育で判定できる。さらに、高温下で菌を生育させれば、耐第性のある酥素を持つ菌だけを選択することができる。こうした変異䤃素選

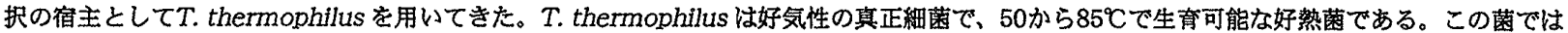

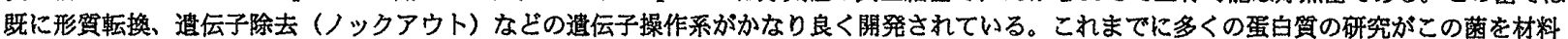
として行われ、ごく最近ではこの菌の全ゲノム塩基配列決定プロジェクトおよび、この菌の全蛋白質の立体棈造解明をめざす「好熱菌一匹丸ご とプロジェクト」が阪大理学部の倉光と理研の横山らを中心に進行中である。先ず、我々は、この菌を宿主として非耐熱性の醉菜の耐熱性を上 昇させるシステムを開発した。枯草菌（Bacillus subtills）、醉母、大渴菌などの常温菌由来のleuB遗伝子を好熱菌内で発現させると、逢生され る酵素の耐熱性が低いためにロイシンなしの培地では低温では生育できるものの高温では生育できない。leuB遗伝子に翂異を導入した後に高温 で生有可能な变異株を選択した。これらの装異株からleuB遗伝子をクローニングし大晹菌内で大组発現させ精製した後にその性資を調べると耐

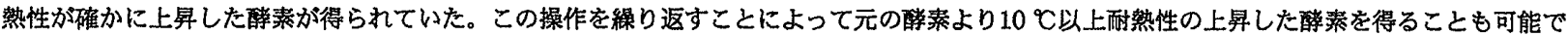

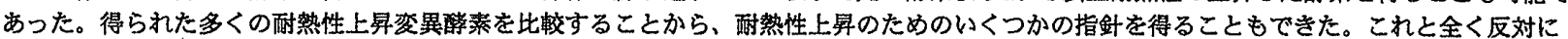

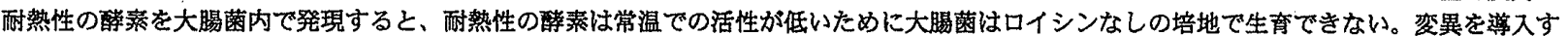
ることによって常温での活性の上昇した醉素を得ることもできた。常温での活性上昇の機權について得られた情報についても紹介したい。

\section{6. 単位領域の組み合わせによる人工タンパタ質の創出}

\section{辻 融、楖川弘志（三菱化学生命科学研究所）}

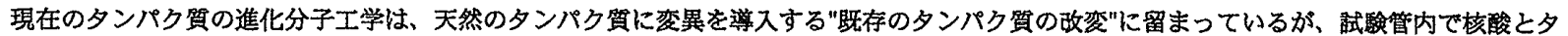

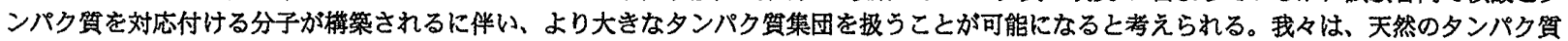
から抽出したペプチド鎖をビルディングブロックとしたコンビナトリアル法と、従来の進化分子工学的手法（最遥化の過程）を組み合わせるこ とにより、広い配列筀間から機能をもつタンパク賀を見出すことができるのではないかと考えている。それではビルディングブロックとしてど のようなペプチド鎖が適当なのだろうか、また単位領域での組み合わせにより權筑されたポリペプチドは、どの程度の橉造形成能や機能をもつ のだろうか。我々は球状タンパク唄のビルディングブロックの候補として、コンパクトな構造を形成するモジュールと、対炤的に伸びた梅造を

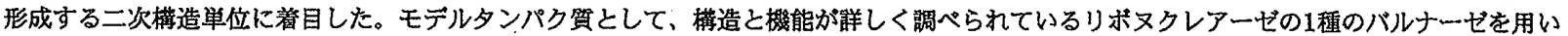
た。バルナーゼを6個のモジール(M1-M6) と二次楧造単位(S1-S6)にそれぞれ分割し、内部の4個の領域を入れ換えた、モジュールおよび二次

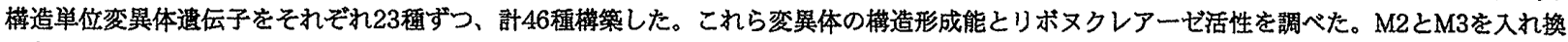
えたM3245と、S3とS5を入れ換えたS2543はモノマーとして存在し、尿素濃度の增加にともない劦同的にunfoldした。また、S2543の1H一 NMRスペクトルのアミドおよびメチルプロトン領域には、シグナルの分散が絸测された。これは、S2543は大幅な変異にもかかからず、二次棈

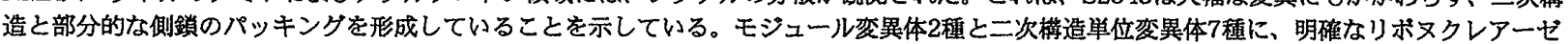
活性が認められた。これらの変異体は至適pHと至適温度をもつなど、酻素としての特性をもつことが確かめられた。これらの瓷異体の活性は、 野生型バルナーゼの1/500から1/3000であった。伸びた榑造である二次榑造単位で入れ換えたS2543が部分的にフォールドした满造を形成した 事実は興味梁い。アミノ酸配列上、近距離と長距離の相互作用の微絮なバランスの上に形成されるタンパク筫の權造形成の埸合、そのビルディ ングブロックが必ずしも一つの安定な構造である必要はなく、むしろ、前後のアミノ酸配列の桨化に適応して複数の安定な楼造を持ち得る゙フレ キシブルなビルディングブロッグの組み合わせにより、フォールドするタンパク賀が楧築できる可能性がある。また最も活性が高いS4523は、

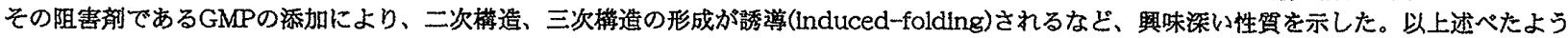
に本年会では、不完全ではあるか醅䇣としての基本的な特性をもつ、モジュールおよび二次構造単位バルナーゼ変異体の物性について紹介し、 単位領域の組み合わせにより新規タンパク筫を楧筑するための、今後の展望について議論したい。 